Alma Mater Studiorum - Università di Bologna DEPARTMENT OF ECONOMICS

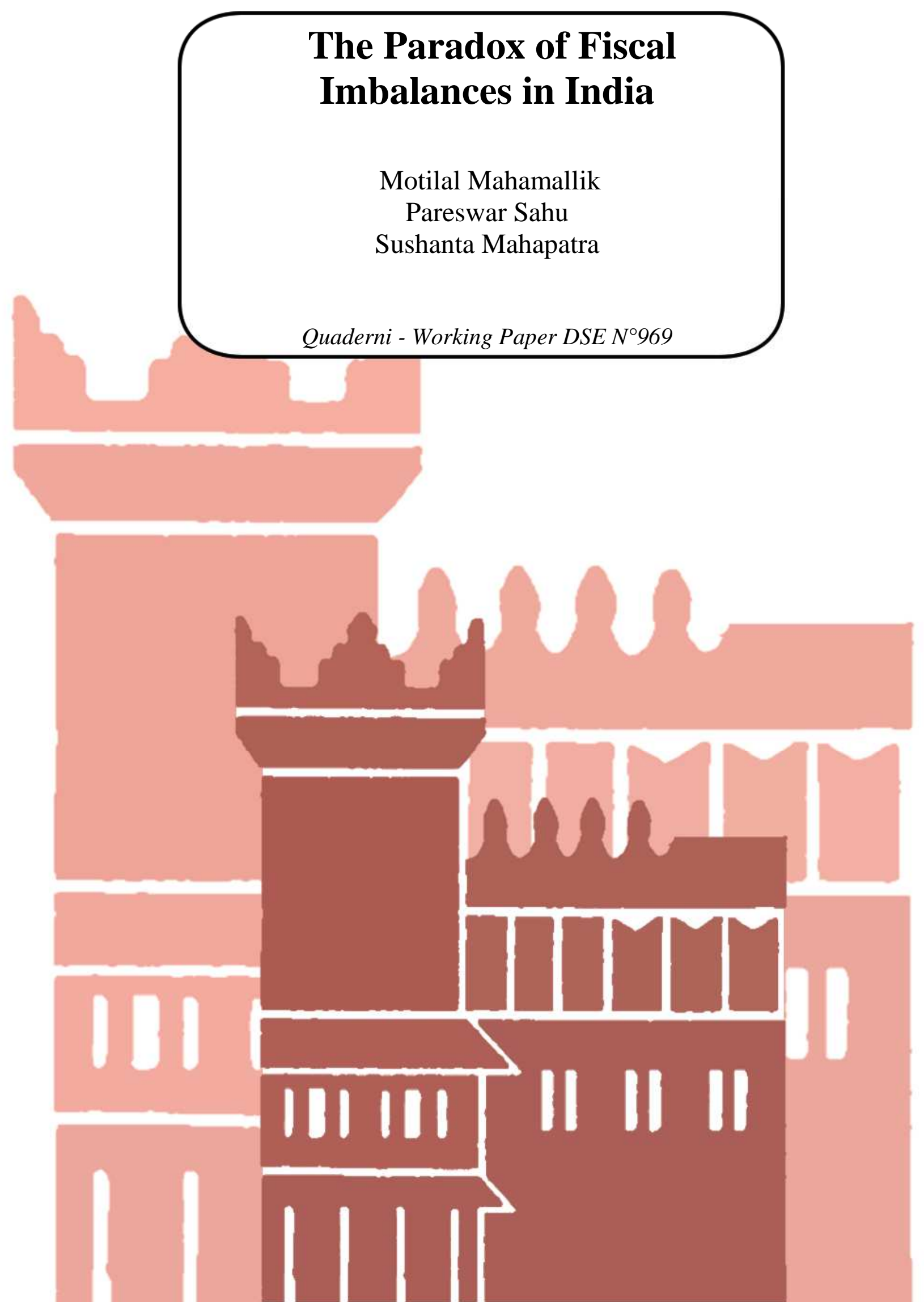




\title{
The Paradox of Fiscal Imbalances in India
}

\section{Motilal Mahamallik, Pareswar Sahue, Sushanta Mahapatra•••}

\begin{abstract}
An attempt has been made to examine the nature and extent of fiscal imbalances in India using the secondary data over a period of thirty years from 1980-81 to 2009-10 (BE). It has been established that there is persistence and growing vertical as well as horizontal fiscal imbalances even after a series of corrective fiscal measures. Efforts to reduce these imbalances found to be ineffective due to contradictions among different measures of fiscal correction. Methodologies adopted to maintain equity contradict with methodologies used to increase efficiency. The $14^{\text {th }}$ finance commission may take initiative to resolve this paradox through a 'weight adjustment solution' which can be helpful in reducing the imbalances. In addition to it, adequate generations of revenue through increasing tax efforts on the part of states and reform in the transfer system are essential for maintaining fiscal balances.
\end{abstract}

Keywords: Fiscal Policy, Vertical and Horizontal Fiscal Imbalances

JEL Classifications Codes: E61, E62, E63

\footnotetext{
- Corresponding Author, Assistant Professor, Institute of Development Studies, 8-B, Jhalana Institutional Area, Jaipur, Rajasthan-302004, INDIA, Contact number +91 141270 5726/ 270 6457, +91 97848 04997, Fax : 91141270 5348, E mail id: moti_m13@rediffmail.com

• Ph D Scholar, P G Department of Economics, Sambalpur University, Sambalpur-768019, Odisha, India, Contact number: +9199375 61035, Email id : pareswar.sahu@gmail.com

•.• Post Doctoral Fellow (European Commission/Union-Erasmus Mundus Programme), Department of Economic Sciences (DSE), University of Bologna, Strada Maggiore 45-40125, Office 19, Bologna, Italy, Italy and Associate Professor (Economics), Amrita School of Business, Kochi Campus, Amrita University, Amrita Institute of Medical Science (AIMS) Campus, AIMS Ponekkara Post, Kochi-682 041, Kerala, India. E-mail id: sushanta.mahapatra@unibo.it, sushanta.mahapatra@gmail.com
} 


\section{Introduction}

The issue of 'fiscal imbalances' has been occupying an important space in 'Indian fiscal federalism' literature because of persistence 'macro economic instability, microeconomic inefficiency and economic inequality'. The fiscal imbalances-vertical and horizontal, are to some extent structural in nature ${ }^{1}$. There has been persistence rising vertical (Chelliah et al 1992, p 2543; Chakraborty, P 1998, p 353; Rao 2003, pp 46-47; Bagchi and Chakraborty 2004) and horizontal imbalances (Mukhopadhyay and Das, 2003, p. 1416 and Rao, 2003, p. 47) observed in India even after a series of measures such as involving new institutions in the transfer system and introducing new policies ${ }^{2}$. The increasing persistence macroeconomic instability with uneven economic growth among states over time certainly raises some pertinent questions on the effectiveness of the sixty-four years old fiscal federalism. The methods ${ }^{3}$ of devolution of the responsible institutions contradict with each other which instead of decelerating, accelerates the imbalances (Chelliah 2005, p 3399). This is because while some methods encourage efficiency others encourage equity ${ }^{4}$. This contradiction is, here and there reflected in literature (Chakraborty 2010, p 57), one of the reasons behind persistence fiscal imbalances.

\footnotetext{
The vertical imbalance occurs (to some extent) due to asymmetric assignment of taxation powers and expenditure responsibilities between different levels of government. The highly income elastic progressive taxation has been assigned to central government while the minor levies like sales tax, taxes on vehicles, taxes on electricity, goods and passengers etc are levied with state governments. In addition to that, more expenditure responsibilities have been assigned to states as compared to centre. Horizontal imbalance arises due to differences in fiscal capacity (Tax-base) or tax efforts, geographical \& climatic condition, and resources endowment within the same level of governments(For details see Seventh Schedule of the Indian constitution; Mukhopadyay, Debes 2003, p 60; Rangarajan, C 2005, p 3396).

2 Under article 280 of the Indian constitution, financial devolution task has been assigned to the Finance Commission (FC). However, the government of India by misinterpreting article 282 directed the Planning Commission (PC) and Central Ministries (CMs) to become a part of the devolution process since inception of the devolution process. At initial level both plan and non-plan transfers were under the control of FC. However, after third FC when the planning process gained momentum, the scope of FC was restricted only to non-plan account and PC and CM were assigned the task to deal with the plan account. However, the CM seek approval of the PC for devolution. Over time, the tax devolutions through FC have been declined due to the negligence of the central government on tax mobilization of central shared tax. In response to that, the $80^{\text {th }}$ constitutional amendment Act 2000 included all central taxes under sharable category to ensure better flow of devolution. Similarly, during $11^{\text {th }}$ and $12^{\text {th }} \mathrm{FC}$, incentives linked restructuring programmes (Medium Term Fiscal Restructuring Programme (MTFRP), 2000-01 to 2004-05 and Fiscal Responsibility Budget Management Act (FRBMA), 2004-05 to 2009-10) have been introduced to reduce (fiscal, primary and revenue) deficits of states'.

3 Responsible institutions have been adopting different methods for devolution of funds to reduce fiscal imbalances. The basic objectives of these methods are to ensure fiscal balances in the country. Finance Commission has adopted gap filling approach, equity principle, fiscal discipline criterion (a part of Gadgil Formula), MTMRP, and FRBMA during different period with varying weights for devolution. In the same line, Planning Commission has been adopting fiscal discipline criterion, equity principle, population and national objectives (as parts of Gadgil Formula) and Central Ministries adopts discretionary methods for devolution.

4 When methods like Fiscal Discipline, MTFRP, and FRBM Act give importance to Efficiency, Equity Principle and Gap Filling Approach gives importance to Equity. Gadgil formula which encourages both efficiency and equity, is a combination of (1) population, equity Principle, Special Problem, and National Objective and Tax effort and fiscal discipline criteria. When the first three criteria encourage equity other two encourages efficiency.
} 
The UFC have used population as the major criterion to distribute income taxes and union excise duty upto $7^{\text {th }}$ and $8^{\text {th }}$ UFC respectively. Thereafter equity principle is used with increasing weight upto $11^{\text {th }}$ UFC period to distribute share taxes as the main criterion. The shift in rising weight from population to equity principle offers more shares to the low fiscal capacity states and less to the high fiscal capacity states ${ }^{5}$. The lower share discourages tax effort. Further the trend of the weight move towards 'efficiency criteria' from 'equity principle' after $11^{\text {th }}$ FC period which encourage states to increase fiscal capacity. Apart from it fiscal restructuring programmes have been introduced to maintain fiscal discipline across states. As a result of use of either equity or efficiency criterion with more weight relative to neutral criteria ${ }^{6}$ over successive finance commission, opportunities were available for states to maximize their share by opting for either of both criteria as their strategy. When significant weight is assigned to equity principle all states prefer to derive benefit from the equity principle, as their strategy, and equity is maintained across states provided the method used as equity principle fulfill its basic characteristics ${ }^{7}$. However, high fiscal capacity states will try to exhibits their status a 'deficient state' in order to avail the benefit of equity principle. In that case, the whole burden will fall on the central government to take care of fiscal health of states. On the other hand, all states will follow the efficiency criterion as their strategy, in case of assignment of significant weight to efficiency criterion and both equity as well as efficiency is maintained without burdening the central government. However, with higher inequality in terms of fiscal capacity across states, this criterion will not help the poorer state in achieving the objective. The assignment of significant weightage to either one of these two principles is not feasible for the development of states. So the challenge is to make a compromise between the weight of equity and efficiency criteria to meet the varying demand of states through mixed strategy which should be taken care of by the $14^{\text {th }}$ UFC.

Shortly the Fourteenth Union Finance Commission (FUFC) is going to submit its report to the Government of India. The commission should use this opportunity and recommend measures to address the issue of increasing fiscal imbalances. This is time to address the issue and rescue the states by arresting factors responsible for increasing fiscal imbalances. There is great expectation by policy makers and scholars of "center state financial relation' on the report of the FUFC which may come out with an amicable solution in the direction of reducing fiscal imbalance.

\footnotetext{
${ }^{5}$ There is inverse relationship between the share of transfer and fiscal capacity of the state.

${ }^{6}$ The neutral criterion includes population and area criteria.

${ }^{7}$ The basic characteristics of equity principles are progressivity, comprehensiveness, neutrality, and exhaustively.
} 
With this background the present paper attempts to re-examine the extent of imbalances using the secondary data over a period of 30 years (1980-81 to 2009-10 (BE)) and analyse the process of contradictions which leads to persistence fiscal imbalances.

The structure of the paper is divided into four parts besides the introduction. Part II analyses the extent of vertical imbalance. Part III is devoted to understand the dynamics and intricacies of horizontal imbalance. In addition to it, the imbalance in pre-and post-reform periods has also been examined. Implementation of suggested measures by center as well as states to reduce imbalances and the contradictions and complementarities across these methods has been analyzed in Part IV. Conclusions and suggestions are discussed in Part V.

\section{Part II}

\section{Vertical Fiscal Imbalance: Extent and Trend}

The vertical imbalance has been examined using own revenue receipt, total receipts, revenue expenditures and total expenditures of states as per cent of their corresponding combination of centre and states ${ }^{8}$. These variables indicate the share of own revenue capacity, total capacity, basic requirements and total requirements of states in their total of both centre and states respectively. Elsewhere the vertical imbalance has also been estimated by using different components of receipts and expenditures of the centre as well as states ${ }^{9}$.

The analysis shows persistence disparities in different components of revenue and expenditure of centre and states. Inequalities exist in (1) own capacity, measured in terms of own revenue, (2) total capacity measured in terms of total receipts, and (3) both revenue as well as total expenditure responsibility of state and centre.

It has been observed that state's share of own revenue capacity is estimated to be $37.5 \%$ (average) as against 55.6\% (average) of revenue expenditure or basic requirement. In other words, the centre has a lion share of own revenue capacity $(62.5 \%)$ and relatively less (44.4\%) basic requirements. The states' share of own revenue capacity has declined at the rate of $0.22 \%$ per year over the three decades. As the rate of decline is very nominal with a

\footnotetext{
The analysis includes 28 states.

The variables used in measuring vertical imbalance are (1) revenue expenditures of states as a per cent of aggregate revenue expenditures of centre and states (2) revenue expenditures of centre as per cent of the aggregate expenditures of centre and states (3) gross tax revenue of the centre as per cent of aggregate revenue of centre and states (4) states capital expenditures as per cent of total combined capital expenditures of centre and states, (5) states total expenditures as per cent of combined total expenditures of centre and states, (6) taxes accrues to the state as per cent of combined taxes of centre and states, (7) taxes accrues to the centre as per cent of total combined taxes of both centre and states,(8) revenue accruals of the state and centre as per cent of their combined revenues. (9) states own revenue as per cent of state revenue expenditures, (10) states own receipts as per cent of states total expenditures, (Chelliah, Rao and Sen 1992, p. 2539-50) (11) states own revenue as per cent of combined revenue receipts of centre and states, and states revenue expenditures as per cent of combined revenue expenditures of centre and states (Chakraborty, Pinaki 1998, p. $353)$.
} 
stark differences at the base, the difference between own revenue of states and combined revenue of centre and states is still maintained.

\section{Table 1: Indicators of Vertical Fiscal Imbalance (in \%)}

\begin{tabular}{|c|c|c|c|c|}
\hline Year & $\begin{array}{l}\text { OR of states as \% } \\
\text { of Combined RR } \\
\text { of center and } \\
\text { states }\end{array}$ & $\begin{array}{l}\text { RE of states as \% of } \\
\text { combined RE of center } \\
\text { and states }\end{array}$ & $\begin{array}{l}\text { TR of states as \% of } \\
\text { combined TR of center } \\
\text { and states }\end{array}$ & $\begin{array}{l}\text { TE of states as \% of } \\
\text { combined TE of } \\
\text { center and states }\end{array}$ \\
\hline $1981-82$ & 37.7 & 58.19 & 42.91 & 57.83 \\
\hline $1982-83$ & 37.7 & 57.63 & 41.09 & 56.27 \\
\hline $1983-84$ & 38.1 & 57.65 & 40.65 & 57.55 \\
\hline $1984-85$ & 37.1 & 57.02 & 41.74 & 56.18 \\
\hline $1985-86$ & 36.7 & 55.26 & 42.49 & 53.06 \\
\hline 1986-87 & 36.2 & 53.81 & 39.80 & 53.20 \\
\hline $1987-88$ & 36.7 & 55.54 & 40.71 & 55.43 \\
\hline 1988-89 & 36.3 & 54.99 & 39.48 & 54.29 \\
\hline 1989-90 & 35.6 & 52.97 & 42.31 & 51.14 \\
\hline 1990-91 & 37.4 & 55.37 & 42.39 & 53.73 \\
\hline $1991-92$ & 38.0 & 57.73 & 44.43 & 57.42 \\
\hline $1992-93$ & 36.9 & 57.71 & 46.90 & 57.00 \\
\hline 1993-94 & 39.8 & 57.04 & 44.45 & 56.26 \\
\hline $1994-95$ & 40.9 & 57.11 & 45.59 & 57.38 \\
\hline $1995-96$ & 39.3 & 56.44 & 46.89 & 56.74 \\
\hline 1996-97 & 37.8 & 56.94 & 45.73 & 57.25 \\
\hline 1997-98 & 39.4 & 56.85 & 44.85 & 57.53 \\
\hline 1998-99 & 38.6 & 54.84 & 42.83 & 55.88 \\
\hline 1999-00 & 37.9 & 55.78 & 47.75 & 56.65 \\
\hline $2000-01$ & 38.7 & 56.01 & 48.36 & 56.63 \\
\hline $2001-02$ & 39.2 & 55.88 & 46.42 & 56.37 \\
\hline $2002-03$ & 38.4 & 54.04 & 49.14 & 52.63 \\
\hline 2003-04 & 37.4 & 55.37 & 55.68 & 51.11 \\
\hline $2004-05$ & 37.7 & 55.57 & 55.01 & 52.16 \\
\hline $2005-06$ & 36.8 & 54.32 & 50.34 & 55.56 \\
\hline 2006-07 & 36.0 & 54.23 & 50.96 & 55.84 \\
\hline $2007-08$ & 34.3 & 54.20 & 48.87 & 54.29 \\
\hline 2008-09 (RE) & 34.7 & 51.47 & 45.75 & 54.33 \\
\hline 2009-10(BE) & 35.0 & 52.30 & 45.21 & 54.48 \\
\hline Average & 37.5 & 55.60 & 45.47 & 55.32 \\
\hline Centre & 62.53 & 44.40 & 54.53 & 44.68 \\
\hline
\end{tabular}

Note: Estimation has been done for 28 states netting out all the basic variables but including interest payment in the revenue expenditures of states. $\mathrm{OR}=$ Own Revenue, $\mathrm{RR}=\mathrm{RR}, \mathrm{TR}=$ Total Receipts, $\mathrm{RE}=$ Revenue Expenditures and $\mathrm{TE}=$ Total Expenditures. RE and BE indicates revised and budget estimates.

Source: For internal debt data of states from 1980-81 to 1990-91, Reserve Bank of India Bulletin various issues (1982-83 to 1993-94) and for internal debt data from 1990-91 to 2009-10 and other variables www.rbi.org.in/occasionalpublication

The combined revenue expenditure of centre and state is estimated to grow at a higher pace $(0.24 \%$ per annum) than that of states. However states have been shouldering the major share $(55.6 \%)$ of basic requirement during the observed period. Rao (2000, p 1884) has also estimated the figure above $50 \%$. 
The share of total capacity (total receipt) of states has been $45.5 \%$ whereas the total requirement (total expenditure) share is found to be $55.3 \%$. Even if the state share of total capacity is growing marginally $(0.97 \%)$ at a higher rate than that of the combined total capacity, it is not able to influence the rate of growth of the ratio.

However the share of total requirement of states is increasing at a higher rate (1\% per annum) than the combined total requirement of centre and states, the trend of the ratio is positive, indicating persistence increase in the expenditure of states.

\section{Part III}

\section{Horizontal Fiscal Imbalance}

Horizontal fiscal imbalance ${ }^{10}$ has been captured through two inter-related but different sets of indicators, (1) components of receipts and expenditure, and (2) deficit indicators. In the first set, the ratio of own revenue to revenue expenditure, own receipts to total expenditure, and revenue expenditure to total expenditure of states have been used to understand the inequality in own revenue capacity (ORC) to meet the basic needs, own total capacity to meet the overall requirements, and the proportion of basic needs in total requirements respectively. Similarly, the second set depicts inequality in deficits faced by states to meet different levels of requirement. Elsewhere fiscal imbalance was also measured using components of receipts, and expenditures ${ }^{11}$.

Three important observations on the imbalance are (1) persistent inequality, (2) growing inequality across states, and (3) further deepening up of inequality in the postliberalization period.

\section{1: Deterioration in Fiscal Health of State}

It is observed that the fiscal health of states has been deteriorated over time (see Table 2). States are on an average in a position to manage $60.5 \%$ of revenue requirements from their own revenue sources which has been declining at an annual rate of $0.47 \%$ over 30 years. As a result, no states are so far found self-sufficient as per the own revenue is concerned. This implies declining tendency in fiscal health of states. The estimate reveals that the average capacity varies from $37.6 \%$ (Bihar) to $82.6 \%$ (Haryana) indicating considerable level of inequality. The inequality is estimated to be growing at $1.2 \%$ per annum pointing towards widening disparity across states. One can observe a huge gap between the mean per capita

\footnotetext{
10 Here the analysis includes 14 major states. The population of 14 major states accounts for $95 \%$ of total population of India (Raju, Swati 2012, p 77) and these states are to some extent similar in industrial units.

11 The horizontal imbalance has been measured through (1) own revenue as a per cent of total expenditure, (2) own revenue as percentage of Net State Domestic Product (Mukhopadhyay et al 2003, pp 1417-19) (3) Own revenue as percentage of GSDP, (4) Per capita GSDP, (5) per capita income and per capita own revenue, (6) per capita current expenditures (7) percentage of own revenue to current expenditures (Rao 2004, p 54: Rao and Sen 1996, pp 106-7).
} 
own revenues (Rs 1423) and mean per capita revenue expenditures (Rs 2282), which has been increasing at $14.5 \%$ per annum. The higher annual rate of growth of mean per capita revenue expenditure $(12.85 \%)$ than that of the mean per capita own revenue $(12.33 \%)$ is responsible for widening the gap. As such high level of inequality between the averages has been noticed across states. The inequality in terms of coefficient of variation $(\mathrm{CV})$ of average per capita own revenue and revenue expenditure are estimated to be $47 \%$ and $28 \%$ in respectively.

Table 2: Extent of Horizontal Imbalance across 14 Major States (1981-82 to 2009-10)

\begin{tabular}{|c|c|c|c|c|c|c|c|}
\hline \multirow[t]{2}{*}{ States } & \multirow[b]{2}{*}{ OR\% RE } & \multicolumn{2}{|c|}{$\%$ of TE } & \multicolumn{4}{|c|}{ Average Per-Capita } \\
\hline & & $\begin{array}{c}\text { Own } \\
\text { Receipt }\end{array}$ & RE & OR & $\begin{array}{c}\text { Own } \\
\text { Receipts }\end{array}$ & $\mathrm{RE}$ & $\mathrm{TE}$ \\
\hline Andhra Pradesh & 63.5 & 57.3 & 77.8 & 1511 & 1811 & 2349 & 3102 \\
\hline Bihar & 37.6 & 34.1 & 76.8 & 390 & 525 & 1191 & 1536 \\
\hline Gujarat & 72.6 & 63.3 & 75.8 & 1817 & 2020 & 2592 & 3361 \\
\hline Haryana & 82.6 & 73.4 & 77.9 & 2520 & 2859 & 3065 & 3803 \\
\hline Karnataka & 72.1 & 65.5 & 77.8 & 1771 & 2052 & 2431 & 3093 \\
\hline Kerala & 60.9 & 59.4 & 82.6 & 1647 & 1988 & 2781 & 3247 \\
\hline Madhya Pradesh & 58.4 & 54.4 & 77.7 & 950 & 1173 & 1697 & 2182 \\
\hline Maharastra & 76.1 & 71.4 & 79.3 & 1974 & 2374 & 2638 & 3322 \\
\hline Orissa & 39.4 & 33.9 & 76.8 & 753 & 724 & 1870 & 2337 \\
\hline Punjab & 71.4 & 64.0 & 75.5 & 2367 & 2857 & 3478 & 4315 \\
\hline Rajasthan & 54.5 & 51.0 & 75.1 & 1016 & 1287 & 1898 & 2451 \\
\hline Tamilnadu & 68.2 & 65.2 & 80.7 & 1828 & 2130 & 2608 & 3213 \\
\hline Uttar Pradesh & 44.7 & 45.4 & 75.9 & 644 & 924 & 1492 & 1937 \\
\hline West Bengal & 45.4 & 45.5 & 80.8 & 734 & 1036 & 1863 & 2282 \\
\hline Mean & 60.5 & 56.0 & 77.9 & 1423 & 1697 & 2282 & 2870 \\
\hline $\mathbf{C V}$ & 23.8 & 22.5 & 2.9 & 47 & 44.7 & 28 & 26.8 \\
\hline
\end{tabular}

Total capacity to meet the overall requirements, estimated by the ratio of 'total own receipt other than loans and grants to total expenditure', is another important indicator to measure horizontal imbalance. This virtually indicates the independent capacity of a state to meet its total expenditure responsibilities. States are on an average in a position to meet only $56 \%$ of their total expenditures from own sources over three decades. It varies from $33.9 \%$ in Odisha to $73.4 \%$ in Haryana. The continuing inequality across states over the period is captured through $\mathrm{CV}$ which is $22.5 \%$ (average). Although the average of total capacity to meet the overall expenditures has increased at an annual rate of $0.14 \%$, the inequality across states gives a grief figure which is growing at $6.4 \%$ per annum. One can notice a huge mean capacity gap between per capita own total receipt (Rs 1697) and per capita aggregate expenditure (Rs 2870). It is also estimated that, the per capita own total capacity difference is 
growing at the rate of $13.2 \%$ per annum. Besides, significant inequality has been observed across states in per capita own total capacity $(44.7 \% \mathrm{CV})$ and per capita total expenditure requirements $(26.8 \% \mathrm{CV})$.

Insignificant inequality $(2.9 \% \mathrm{CV})$ across states in the proportion of revenue expenditures to total expenditures was noticed because of marginal difference between numerator and denominator variables maintained by states. However, a stark inequality was estimated (high CV) across states while considering both variables separately. It is estimated that in three decades the average ratio of both variables is more or less $78 \%$ implying more than two third of the total expenditure is spent for basic needs by states. It is highest in Kerala with $82.6 \%$ and lowest in Rajasthan with $75.1 \%$. As mentioned earlier, the inequality across states in per capita revenue expenditure $(28 \% \mathrm{CV})$ and per capita total expenditure $(26.8 \%$ CV) found significant.

\subsection{Inequality under Dis-aggregation:}

The disaggregated analysis across different income group states shows widening inequality ${ }^{12}$. Inequality in ORC to meet the basic needs measured in terms of CV found very high across LIGS (19.5\%) followed by MIGS (16.5\%) and HIGS $(6.7 \%)$. It is estimated that on an average LIGS are in a position to manage around $50 \%$ of their basic needs from ORC, which is $62 \%$ and $75 \%$ among the MIGS and HIGS respectively. ORC to meet the basic needs has been declining at an annual rate of $0.52 \%, 0.23 \%$ and $0.54 \%$ for HIGS, MIGS and LIGS respectively. In addition to it, the inequality across the HIGS increased at the rate of $26.3 \%$ per annum followed by MIGS (6.3\%) and LIGS (3.1\%). Decrease in ORC to meet basic needs and increasing inter and intra group inequality clearly speaks about the frustrating economic instability.

It is interesting to note that there are significant imbalances observed in the per capita capacity as well as needs across three income groups states. The three decades averages per capita ORC for HIGS is nearly 2.6 times higher than that of the LIGS. Similarly, the per capita expenditure inequality found to be growing at the rate of $14.1 \%, 6.2 \%$ and $7.8 \%$ per annum for HIGS, MIGS and LIGS respectively. The inequality in own revenue and expenditure remains intact among these groups as the rate of growth in per capita ORC is more or less same (around 12\% per annum), so also the per capita expenditure (12.8 to $13 \%$ per annum).

12 The states have been divided into High Income Group States (HIGS), Middle Income Group States (MIGS) and Low Income Group States (LIGS). Mean per capita NSDP of 14 major states over 30 years has been taken as a dividing line for LIGS. States such as Bihar, Orissa, UP, MP and Rajasthan, fall under this category. The combined mean of the mean per capita income of states except LIGS has been used to divide states into HIGS and MIGS. 


\subsection{Imbalances after liberalization:}

Improvement in the quality of infrastructure is one of the prerequisites to accelerate the growth process (Rao 2002, p 3261). The market-based reform generates more inequality when there is unequal capacity among states for infrastructure development. There are evidences of divergences in growth performances among states because of unequal capacity for infrastructure in the post reform era (Ahluwalia 2000). The major challenge faced by poorer states in the post reform period is to chase competitive infrastructure investment in order to attract foreign capital investment. States with infrastructure or capacity to invest on infrastructure perform well; whereas, others found struggling even to meet the basic needs. With this backdrop, this part will explore the imbalances in pre and post-liberalization periods.

The ORC to meet the basic needs has gone down from $64.2 \%$ in pre-liberalization to $58.4 \%$ in post liberalization period. The inequality captured through $\mathrm{CV}$ across states after economic reforms has increased from $20.7 \%$ to $26 \%$ (see Table 3). Capacity and inequality among different income group states shows the same trend, even though the per capita own revenue as well as revenue expenditure has considerably increased during post reform period. This also complemented with higher inequality across states during post reform period.

The proportion of own total receipt to total expenditure has increased from $54.9 \%$ in pre-reform period to $56.9 \%$ in post reform period. When the average of own receipt reported 8.64, the average of total expenditure reported 8.37 fold jump from pre-to post-reform period. The relatively higher jump in the earlier variable than the later variable makes the proportion unequal. Inequality has widened in the post reform by $5 \%$ more than the pre reform period. The share of revenue expenditure in total expenditures has increased from $73 \%$ during prerefom to $81 \%$ during post-reform period. The rise was around $10 \%$ and $9 \%$ for HIGS and LIGS, whereas it is $4 \%$ for the MIGS, indicating less scope for capital investment in former two groups.

Table 3: Horizontal Fiscal Imbalance (14 Major States) in Pre and Post Liberalization

\begin{tabular}{lcccc}
\hline & \multicolumn{2}{c}{ Pre- Liberalization } & \multicolumn{2}{c}{ Post- Liberalization } \\
\cline { 2 - 5 } & Mean & CV & Mean & CV \\
\hline \% of OR to RE & 64.2 & 20.7 & 58.4 & 26 \\
\hline$\%$ Own total Receipts to TE & 54.5 & 19.6 & 56.9 & 24.6 \\
\hline$\%$ of RE to TE & 72.9 & 5.8 & 80.8 & 2.9 \\
\hline$\%$ of Capital Expenditure to TE & 27.2 & 15.6 & 19.2 & 12.3 \\
\hline $\begin{array}{l}\text { Note: } \quad \text { The acronyms are same as Table 1. } \\
\text { Source: Same as Table 1. }\end{array}$ & & & & \\
\end{tabular}




\subsection{Deficit Indicators: What do they speak about?}

Wide variation in the deterioration in fiscal situation of states estimated with the help of deficit indicators has been widely discussed in literature (Rao 2002, p 3263).

Per capita RD, FD and PD of sample states have been growing at 27.05, 11.53 and $61.85 \%$ respectively (figure 1$)^{13}$ indicating financial deterioration of states during the observed period. While the proportions of RD and FD as a percentage of the GSDP shows positive slopes, PD as percentage of GSDP gives a reverse trend indicates lower rate of growth of PD than that of GSDP (figure 2 \& Table 4). Rao (2002, p 3262; 2003, p 53 and 2004, p 1821) has also observed the increasing trend of RD, FD and PD as a percentage of GDP during 1980-81 to 2001-02. However, a declining trend has been observed in the PD from 2003-04 to 2007-08 that further took a positive slope after 2007-08. Declining trend in PD may be observed due to the higher rate of growth of interest payment than that of the FD. Elsewhere, it has also been mentioned that deterioration in the state finances is due to the rise in the percentage of interest payment over the years (Rao 2000, p 54).

\section{Figure 1: Per Capita Deficit Indicators of States (in average)}

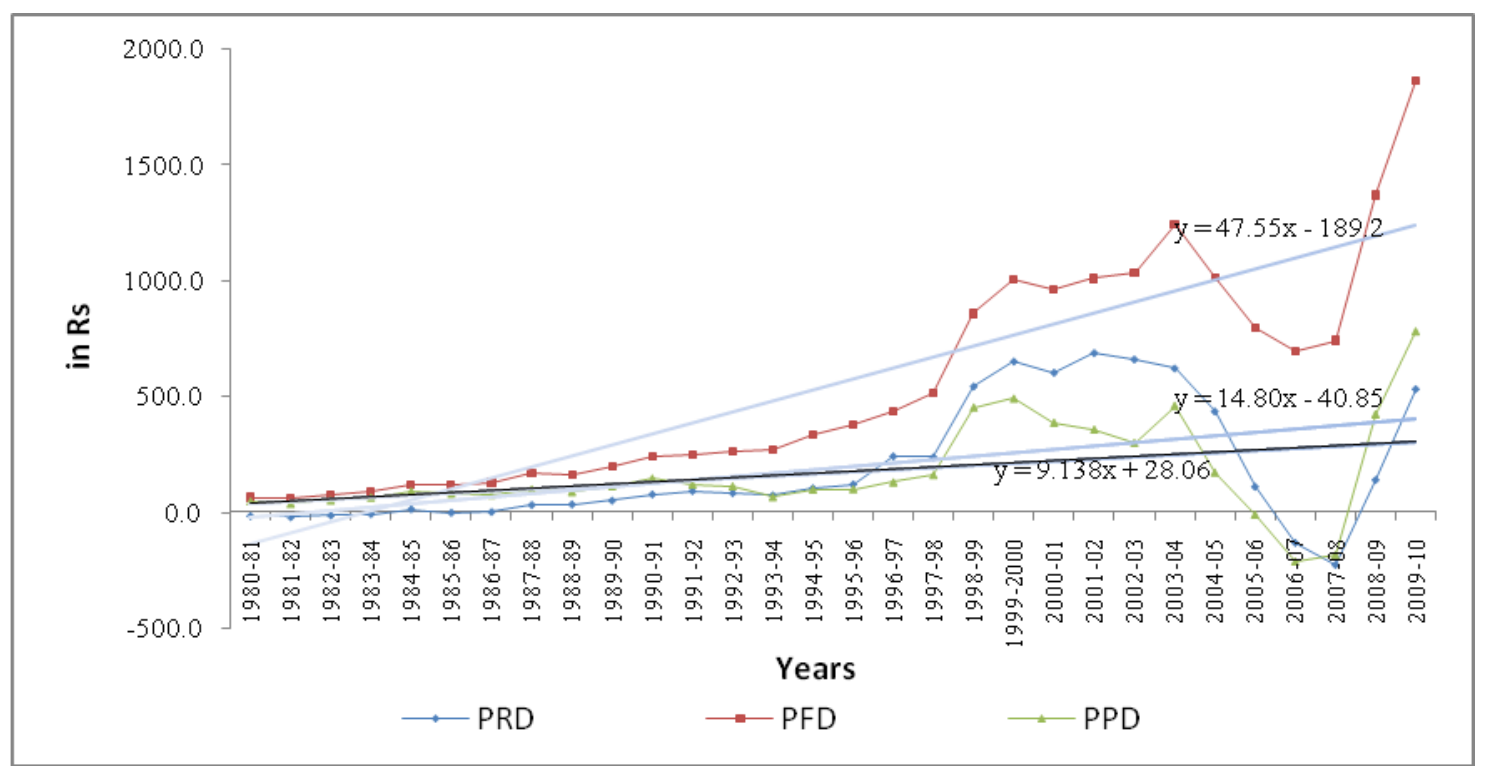

13 While RD indicates the inability to meet the basic needs, the efforts for basic needs as well as further investment is captured by FD. In other words, accumulation of public debt, interest payment and RD constitutes the major components of FD (Rakshit 2005, p 3440). Closer the RD to FD, lesser is the scope for further growth which in turn accelerates debt burden in the form of PD. The growth rate of deficits has been estimated from deficits year's figures of sample states. Even though few states have shown surplus figures in few years, the present estimation excluded these years as the objective here is to estimates the trend of deficit. It is worthy to note that, in case of PD and FD most of the states have deficit figures with few exceptions. However, RD figures of sample states are a mix-up of both surplus and deficits. 
Figure 2: Trend in Deficit Indicators (as percentage of GSDP)

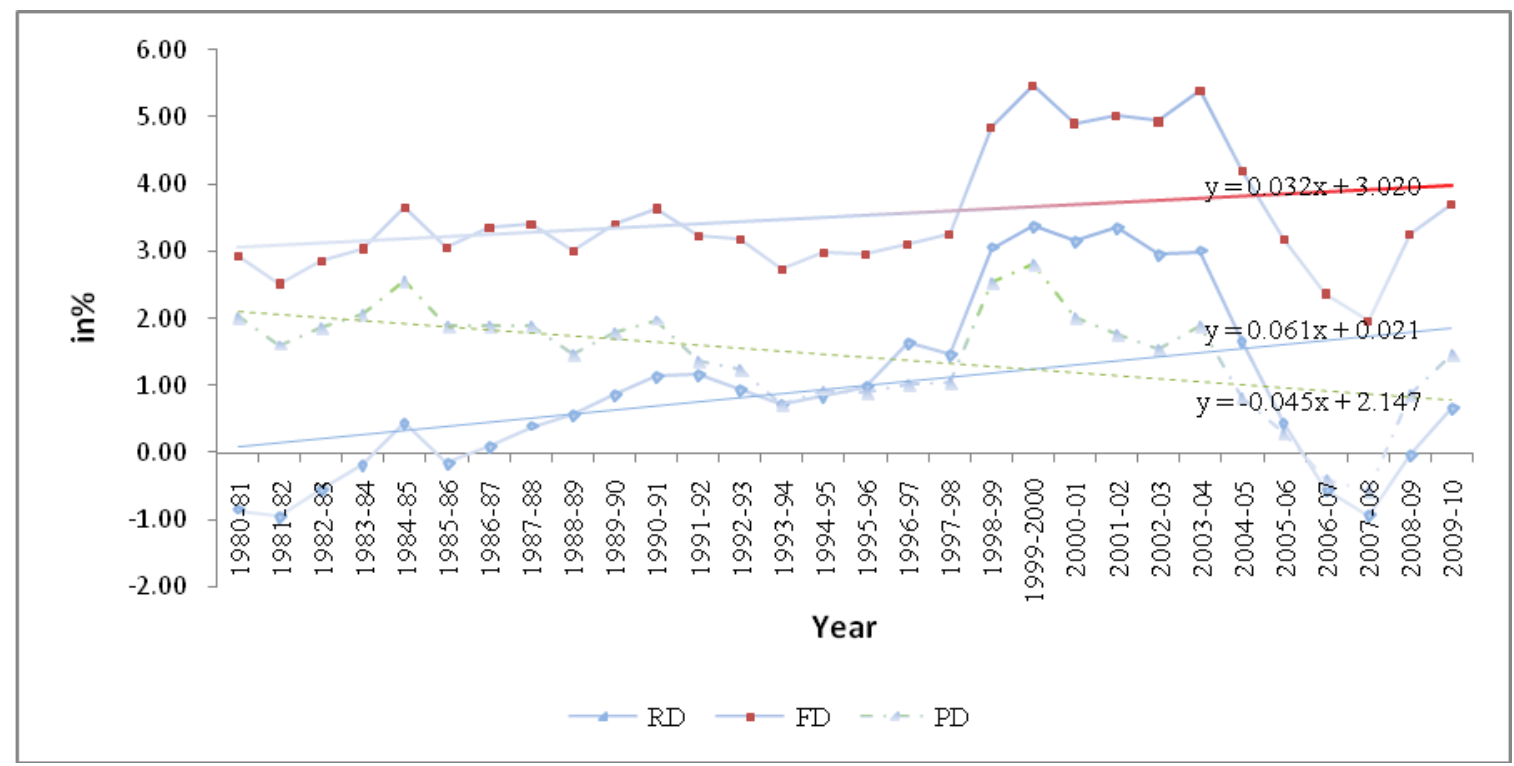

Table 4: RD, FD and PD of 14 major states (Rs Crores)

\begin{tabular}{lccc}
\hline YEAR & RD & FD & PD \\
\hline $1980-81$ & $-1066(-0.85)$ & $3674(2.94)$ & $2535(2.03)$ \\
\hline $1981-82$ & $-1352(-0.94)$ & $3608(2.52)$ & $2268(1.58)$ \\
\hline $1982-83$ & $-860(-0.55)$ & $4495(2.87)$ & $2921(1.86)$ \\
\hline $1983-84$ & $-304(-0.16)$ & $5658(3.04)$ & $3856(2.07)$ \\
\hline $1984-85$ & $916(0.45)$ & $7484(3.65)$ & $5245(2.56)$ \\
\hline $1985-86$ & $-313(-0.14)$ & $7045(3.06)$ & $4386(1.9)$ \\
\hline $1986-87$ & $280(0.11)$ & $8548(3.36)$ & $4836(1.9)$ \\
\hline $1987-88$ & $1138(0.39)$ & $9892(3.40)$ & $5500(1.89)$ \\
\hline $1988-89$ & $1995(0.57)$ & $10443(3.0)$ & $5105(1.47)$ \\
\hline $1989-90$ & $3509(0.88)$ & $13627(3.41)$ & $7151(1.79)$ \\
\hline $1990-91$ & $5400(1.16)$ & $16965(3.64)$ & $9122(1.96)$ \\
\hline $1991-92$ & $6421(1.18)$ & $17492(3.22)$ & $7436(1.37)$ \\
\hline $1992-93$ & $5843(0.94)$ & $19722(3.19)$ & $7772(1.26)$ \\
\hline $1993-94$ & $5273(0.73)$ & $19676(2.73)$ & $5202(0.72)$ \\
\hline $1994-95$ & $7213(0.85)$ & $25353(2.99)$ & $7742(0.91)$ \\
\hline $1995-96$ & $9675(0.99)$ & $28932(2.96)$ & $8779(0.9)$ \\
\hline $1996-97$ & $18458(1.64)$ & $34899(3.1)$ & $11437(1.02)$ \\
\hline $1997-98$ & $18406(1.47)$ & $40538(3.25)$ & $12999(1.04)$ \\
\hline $1998-99$ & $43360(3.05)$ & $69022(4.86)$ & $36044(2.54)$ \\
\hline $1999-2000$ & $52616(3.39)$ & $84889(5.47)$ & $43640(2.81)$ \\
\hline $2000-01$ & $51549(3.16)$ & $80034(4.91)$ & $32780(2.01)$ \\
\hline $2001-02$ & $58980(3.37)$ & $87909(5.03)$ & $30896(1.77)$ \\
\hline $2002-03$ & $55837(2.97)$ & $92902(4.94)$ & $29004(1.54)$ \\
\hline $2003-04$ & $64006(3)$ & $115146(5.4)$ & $40446(1.9)$ \\
\hline $2004-05$ & $40019(1.68)$ & $100320(4.2)$ & $19918(0.83)$ \\
\hline $2005-06$ & $12171(0.45)$ & $85860(3.18)$ & $8107(0.3)$ \\
\hline $2006-07$ & $-17140(-0.55)$ & $74594(2.37)$ & $-12080(-0.38)$ \\
\hline $2007-08$ & $-33173(-0.91)$ & $71577(1.96)$ & $-20925(-0.57)$ \\
\hline $2008-09(\mathrm{RE})$ & $-675(-0.02)$ & $135283(3.25)$ & $36875(0.89)$ \\
\hline $2009-10(B E)$ & $33136(0.68)$ & $178782(3.7)$ & $70826(1.46)$ \\
\hline$N 05$. & & \\
\hline
\end{tabular}

Notes: Figures in the brackets are per cent of GSDP

Source: For GSDP, CSO and the source of other variables are same as Table 1. 
States were in a position to go for further capital investment covering revenue expenditure responsibility from own revenue sources till 1985-86. However the scope of capital investment was reduced when RD showed positive trend during 1986-87 to 2003-04. This in turn led to further rise in RD. The increasing trend in RD accentuated with the implementation of $5^{\text {th }}$ pay commission in 1997-98 (Rao 2003 p.53, Rao 2002 p 3262). The per cent of RD to FD (quality of deficit) has increased from $12 \%$ in $1987-88$ to $67 \%$ in $2001-02$ with the implementation of the recommendations of fifth pay commission. In the same line FD as per centage of GSDP, being influenced by the trend of RD due to their natural relationship, has increased (2.5\% per annum) during the same period. RD decline after 2003 04 continuously generating revenue surplus and reducing FD with the hope of getting the conditional benefit of MTFRP.

The rate of growth of PD as a percentage of GSDP has been increasing at $11.8 \%$ per annum in three decades, indicating acceleration in outstanding loan. The increasing deficits both in per capita as well as ratio of GSDP clearly speaks about the increasing gap burden to meet different levels of need. The accumulation of loan has an adverse impact on capital formation (Lalvani, Mala 2009, p 59) as well as compels states either (1) to reduce the expenditure on social and economic service (Rao and Sen 1996; Varghese 2006) or (2) to increase the revenue deficit. It certainly leads to the deterioration in the fiscal health of states (Rao 2004, p 1821).

Five inferences can be drawn from the analysis of deficit indicators, (1) debt burden is mounting, (2) No scope for expansion in social and economic service, (3) no scope for capital investment, (4) there is stark inequality among states and (5) the process of devolution of revenue is ineffective.

\section{Part IV}

\section{The Paradox of Fiscal Imbalances}

The observed persistence rising fiscal imbalances in India is a bi-product of policy paradox. Efforts to reduce these imbalances work like a boomerang against the principles of fiscal federalism. Complementarities among methodologies having same objectives and contradictions among methodologies with different objectives adopted by UFC and PC accelerate the pace of imbalances. In other words, methodologies adopted to maintain equity complements with each other. Similarly methodologies used to maintain efficiency also complements each other. However, methodologies adopted to maintain equity contradicts with methodology used to increase efficiency (See Table 8). 


\subsection{Deficit versus Economic Growth}

In the name of growth, centre as well as states increased their deficits over time through different ways ${ }^{14}$. Centre has experienced deficits at different points of time for a variety of reasons (See Appendix I). Increase in the state's share in shareable central taxes rise in staff salary and pension after implementation of the fifth pay commission and interest payment are responsible for the rise in both $\mathrm{RD}$ and FD of centre.

Table 5: State Finances from $7^{\text {th }}$ to $8^{\text {th }}$ FC (\%GSDP)

\begin{tabular}{|c|c|c|c|c|c|c|}
\hline States & OR & CST & GR & $\mathbf{R R}$ & RE & RD \\
\hline \multicolumn{7}{|l|}{ HIGS } \\
\hline Gujarat & 1.2 & -0.26 & 0.36 & 1.26 & 3.02 & 1.84 \\
\hline Haryana & 1.1 & -0.25 & 0.60 & 1.42 & 1.80 & 0.40 \\
\hline Maharastra & 1.1 & -0.19 & 0.39 & 1.27 & 2.38 & 1.10 \\
\hline Punjab & -0.2 & -0.21 & 0.48 & 0.12 & 1.49 & 1.40 \\
\hline Average & 0.79 & -0.23 & 0.46 & 1.02 & 2.17 & 1.18 \\
\hline \multicolumn{7}{|l|}{ MIGS } \\
\hline Andhra Pradesh & 1.8 & 0.23 & 0.33 & 2.36 & 3.33 & 0.98 \\
\hline Karnataka & 0.6 & -0.08 & 0.43 & 0.94 & 2.35 & 1.41 \\
\hline Kerala & 0.5 & -0.17 & 0.68 & 0.99 & 2.30 & 1.21 \\
\hline Tamilnadu & -0.2 & -0.21 & 0.31 & -0.11 & 0.80 & 0.93 \\
\hline West Bengal & 0.3 & 0.07 & 0.71 & 1.11 & 0.79 & -0.29 \\
\hline Average & 0.60 & -0.03 & 0.49 & 1.06 & 1.91 & 0.85 \\
\hline \multicolumn{7}{|l|}{ LIGS } \\
\hline Bihar & 1.3 & 0.11 & 0.41 & 1.80 & 0.79 & -1.01 \\
\hline Madhya Pradesh & 0.2 & 0.22 & 0.25 & 0.70 & 2.19 & 1.50 \\
\hline Orissa & 0.2 & 0.54 & -0.73 & -0.03 & 1.21 & 1.27 \\
\hline Rajasthan & -0.7 & -0.25 & 0.81 & -0.13 & 1.68 & 1.84 \\
\hline Uttar Pradesh & 0.4 & 0.57 & 0.15 & 1.09 & 2.10 & 1.01 \\
\hline Average & 0.27 & 0.24 & 0.18 & 0.69 & 1.60 & 0.92 \\
\hline
\end{tabular}

Note: $\quad$ OR $=$ Own Revenue, CST = Central Shared Taxes, GR = Grants from the Centre to States, RR = Revenue Receipts, $\mathrm{RE}=$ Revenue Expenditures and $\mathrm{RD}=$ Revenue Deficit and the (+) and (-) sign represents the increase or decrease between the two FC periods. GSDP is taken as current price.

Source: Same as Table 4.

In the same line the finances of states also estimated to decline sharply in $8^{\text {th }}$ UFC as discussed in section 3.4 (See Appendix I and Figure 1). It was observed that from $7^{\text {th }}$ to $8^{\text {th }}$ UFC period RD increased by $1 \%$ due to excess of revenue expenditure over the revenue receipt. The rise in expenditures on social $(0.66 \%)$ and economic services $(0.49 \%)$, interest payment $(0.41 \%)$, administrative services $(0.1 \%)$ and pension $(0.21 \%)$ has given rise to the increase in revenue expenditures. The inter-grouping analysis shows that HIGS and LIGS have experienced more deterioration as compared to MIGS (See Table 5). In the former

14 Different schools of thoughts have their opinion on the effect of deficits on growth. Neo classical are of the view that deficit financing is not a viable tool for economic growth as it might drag the economy to depression through lower levels of equilibrium. However, Keynesians are optimistic about the growth through FD, till reaching the level of full employment. Ricardo however believes in the neutral effect of FD on growth. It is believed that these frame work seldom work, if at all it might for small time period which further lack empirical as well as theoretical evidences. These theories are applicable depending on the larger number of populations on which they base (Rangarajan and Srivastava 2005, p 2921). 
groups of state deterioration increased by $1.2 \%$ and $0.92 \%$ from $7^{\text {th }}$ to $8^{\text {th }}$ UFC respectively due to more than 2 folds rise in revenue expenditures than revenue receipt (RR). The rise in revenue expenditure of HIGS is because of the rise in expenditures on social $(0.88 \%)$ and economic services $(0.31 \%)$, interest payment $(0.48 \%)$, administrative services $(0.13 \%)$ and pension $(0.25 \%)$ and decline in central shared taxes $(0.23 \%)$. Similarly the rise in revenue expenditure of LIGS are due to the rise in expenditure on social $(0.33 \%)$ and economic services $(0.75 \%)$, interest payment $(0.4 \%)$, administrative services $(0.1 \%)$ and pension $(0.14 \%)$.

Keeping in view the declining financial situation, the central government directed states during $9^{\text {th-2 }}$ FC to control RD as well as FD and increase capital investment through remedial measures. However, the finances of states instead of improving deteriorated sharply due to lack of remedial measures. The share of revenue expenditures of states increased 4 times of $\mathrm{RR}$ from $8^{\text {th }}$ to $9^{\text {th-2 }} \mathrm{FC}$ leading to increase in $\mathrm{RD}(0.7 \%)$. It is because of rise in interest payment $(0.54 \%)$, pension $(0.11 \%)$ and miscellaneous general economic services $(0.37 \%)$ and constant central shared taxes and grants and marginal rise $(0.1 \%)$ in own revenue of states. The inter grouping state estimation reflects that the deterioration is more in LIGS. However it is relatively more in HIGS and MIGS than LIGS (see Table 6). The revenue expenditures increased by $0.6 \%$ and $0.1 \%$ and RR declined by- $0.1 \%$ and $-0.5 \%$ in HIGS and MIGS respectively. The own tax laxity as well as the decline in central shared taxes and grants has contributed in reducing the RR.

The RD of all states (average) increased by $1.2 \%$ between $9^{\text {th }}$ to $10^{\text {th }}$ UFC due to decline in the RR $(-1.3 \%)$ given the same level of revenue expenditures. The decline in the share of central shared taxes $(-0.1 \%)$ due to reduction in tax-GDP ratio of the centre, and grants $(-0.7 \%)$ to states as well as the own revenue $(-0.5 \%)$ due to decline in the tax effort and tax exemption to attract new investment has led to reduction in RR. The increase in the interest payment due to mounting of borrowing and rise in salary and pension with the implementation of fifth pay commission have given rise to the constancy in revenue expenditures (Kurian 2005, p 3429; Ghosh 2005, p 3436). It is further observed that the deterioration is more in HIGS and LIGS than MIGS (See Table 7). RD increased due to decline in RR $(0.9 \%)$ as well as rise in revenue expenditure $(0.2 \%)$ in HIGS. The significant decline in own revenue $(0.6 \%)$ as well as marginal fall in central shared taxes $(0.1 \%)$ and grants $(0.2 \%)$ has been responsible for the fall in RR. The increase in interest payment $(0.5 \%)$ and pension $(0.3 \%)$ over the reduction of social and economic expenditures $(0.6 \%)$ has led to rise in revenue expenditures. In LIGS the RD increased due to significant decline in RR (- 
$1.6 \%)$ and rise in revenue expenditure $(0.1 \%)$. The reduction of own revenue $(-0.4 \%)$ and grants $(-1.1 \%)$ has reduced the RR.

Table 6: State Finances from $8^{\text {th }}$ to $9^{\text {th-2 }}$ FC (\%GSDP)

\begin{tabular}{|c|c|c|c|c|c|c|}
\hline States & OR & CST & GR & $\mathbf{R R}$ & RE & RD \\
\hline \multicolumn{7}{|l|}{ HIGS } \\
\hline Gujarat & 0.5 & -0.29 & -0.50 & -0.25 & -0.13 & 0.05 \\
\hline Haryana & 1.7 & -0.03 & -0.68 & 0.99 & 2.10 & 1.11 \\
\hline Maharastra & -1.4 & -0.29 & -0.21 & -1.94 & -2.15 & -0.21 \\
\hline Punjab & 1.1 & -0.04 & -0.28 & 0.77 & 2.49 & 1.72 \\
\hline Average & 0.5 & -0.2 & -0.4 & -0.1 & 0.6 & 0.7 \\
\hline \multicolumn{7}{|l|}{ MIGS } \\
\hline Andhra Pradesh & -1.9 & -0.37 & -0.03 & -2.32 & -2.36 & -0.05 \\
\hline Karnataka & -0.2 & -0.21 & -0.10 & -0.54 & -0.65 & -0.11 \\
\hline Kerala & -0.1 & 0.02 & -0.05 & -0.17 & 0.24 & 0.52 \\
\hline Tamilnadu & 0.5 & -0.11 & -0.06 & 0.30 & 2.31 & 2.01 \\
\hline West Bengal & 0.0 & 0.16 & -0.02 & 0.17 & 1.10 & 0.92 \\
\hline Average & -0.4 & -0.1 & -0.1 & -0.5 & 0.1 & 0.7 \\
\hline \multicolumn{7}{|l|}{ LIGS } \\
\hline Bihar & -0.3 & 0.18 & 0.61 & 0.48 & 4.11 & 3.03 \\
\hline Madhya Pradesh & -0.2 & -0.19 & 0.33 & -0.11 & 0.19 & 0.30 \\
\hline Orissa & 0.7 & 1.09 & 0.51 & 2.33 & 2.60 & 0.28 \\
\hline Rajasthan & 0.4 & 0.25 & -0.04 & 0.65 & -0.12 & -0.78 \\
\hline Uttar Pradesh & 0.4 & -0.08 & 0.75 & 1.10 & 2.26 & 1.19 \\
\hline Average & 0.2 & 0.2 & 0.4 & 0.9 & 1.8 & 0.8 \\
\hline
\end{tabular}

Note: $\quad$ Same as Table 5.

Source: Same as Table 4.

Table 7: State Finances from $9^{\text {th-2 }}$ to $10^{\text {th }}$ FC (\%GSDP)

\begin{tabular}{|c|c|c|c|c|c|c|}
\hline States & OR & ST & GR & $\mathbf{R R}$ & RE & RD \\
\hline \multicolumn{7}{|l|}{ HIGS } \\
\hline Gujarat & -0.8 & 0.11 & -0.24 & -0.96 & -0.16 & 0.80 \\
\hline Haryana & -0.4 & -0.08 & -0.08 & -0.61 & 1.21 & 1.82 \\
\hline Maharastra & -0.9 & -0.31 & -0.38 & -1.61 & -0.60 & 1.00 \\
\hline Punjab & -0.1 & -0.13 & -0.27 & -0.55 & 0.21 & 0.76 \\
\hline Average & -0.6 & -0.1 & -0.2 & -0.9 & 0.2 & 1.1 \\
\hline \multicolumn{7}{|l|}{ MIGS } \\
\hline Andhra Pradesh & -0.9 & 0.03 & -0.44 & -1.28 & 0.04 & 1.32 \\
\hline Karnataka & -0.5 & 0.02 & -0.40 & -0.88 & -0.26 & 0.62 \\
\hline Kerala & 0.1 & -0.22 & -0.69 & -0.82 & 0.21 & 1.03 \\
\hline Tamilnadu & -0.5 & -0.46 & -0.59 & -1.55 & -1.91 & -0.36 \\
\hline West Bengal & -1.0 & -0.23 & -0.56 & -1.80 & 0.06 & 1.86 \\
\hline Average & -0.6 & -0.2 & -0.5 & -1.3 & -0.4 & 0.9 \\
\hline \multicolumn{7}{|l|}{ LIGS } \\
\hline Bihar & -0.5 & 0.60 & -1.05 & -0.92 & -0.90 & -0.08 \\
\hline Madhya Pradesh & 0.0 & 0.15 & -0.72 & -0.62 & 0.92 & 1.53 \\
\hline Orissa & -0.6 & -0.74 & -1.13 & -2.47 & 0.43 & 2.90 \\
\hline Rajasthan & -0.6 & -0.40 & -1.33 & -2.29 & -0.16 & 2.13 \\
\hline Uttar Pradesh & -0.5 & 0.30 & -1.52 & -1.71 & 0.03 & 1.74 \\
\hline Average & -0.4 & 0.0 & -1.1 & -1.6 & 0.1 & 1.6 \\
\hline
\end{tabular}

Note: $\quad$ Same as Table 5.

Source: Same as Table 4. 
MTFRP was introduced to bring improvement in the fiscal health of states during $11^{\text {th }}$ FC period (See Table 8). It was also supplemented by tax effort and fiscal discipline criterion with the weightage of $5 \%$ and $7.5 \%$ respectively ${ }^{15}$. The inter-grouping estimation shows that RD is more in HIGS and MIGS than LIGS (see Appendix II). It is also observed from intra grouping estimation that even if there is reduction of RD in Haryana, Tamilnadu, MP and Odisha and marginal increase in RD has been observed in other LIGS. However, high deficits are found in rest of HIGS and MIGS.

In Haryana the reduction in $\mathrm{RD}(1.25 \%)$ is due to higher $(-1.3 \%)$ decline in revenue expenditures than the RR. The shares of own revenue, central shared taxes and grants have declined by $-1.7 \%,-0.4 \%$ and $-0.1 \%$ respectively from $10^{\text {th }}$ to $11^{\text {th }}$ FC period while revenue expenditures by $-3.5 \%$ of GSDP. Tamilnadu experienced marginal (-0.06\%) fall in RD due to marginal rise $(0.05 \%)$ in $\mathrm{RR}$ over revenue expenditure despite the decline in central shared taxes $(-0.2 \%)$. It has been estimated that in Tamilnadu the own revenue and grants have increased by 1 and $0.15 \%$ respectively. It has been observed that the share of central shared taxes in both Haryana and Tamilnadu has declined due to rise in the weightage $(2.5 \%)$ of income distance method used in the distribution of such taxes than the previous commission.

In Odisha RR has increased $2.43 \%$ more than revenue expenditures leading to $0.6 \%$ decline in RD. The own revenue, central shared taxes and grants have increased by $1.5 \%$, $1.2 \%$ and $0.13 \%$ respectively while the revenue expenditures has increased by $0.4 \%$. Similarly $0.23 \%$ decline in RD has been observed in MP. It is because the RR has marginally $(0.27 \%)$ increased over revenue expenditures. In all other LIGS the revenue expenditures have increased more than the own revenue. But due to greater weightage assigned to the income distance criterion the share of central shared taxes of these states has increased leading to low RD.

However, increased deficits have been observed in all other HIGS and MIGS. The deficits increased to a greater extent in Gujarat, Maharastra, Punjab of HIGS, Kerala and West Bengal of MIGS. In Gujarat the revenue expenditures have increased $1.98 \%$ more than the RR leading to rise in RD. The own revenue and grants have marginally $(0.1 \%$ and $0.58 \%$ respectively) increased along with fall in central shared taxes by $-0.35 \%$. The own revenue of Gujarat has observed to be constant due to the tax exemptions and subsidy offered by the state. Otherwise it could have registered a growth during this period. In addition to that,

15 The increase in tax effort and fiscal discipline measured in terms of improvement in own revenue as per cent of total revenue expenditures increases the share of state in central shared taxes and vice versa which in turn helps in reducing or increasing the $\mathrm{RD}$ respectively. 
higher weightage of income distance criterion led to the reduction of central shared taxes. However the revenue expenditures have increased by $2.3 \%$ leading to $1.98 \%$ rise in RD. The revenue expenditures have increased $1.61 \%$ more than the RR in Maharashtra which leading to rise in deficits by $1.63 \%$. Although the own revenue has increased marginally $(0.7 \%)$ the decline in central shared taxes $(-0.18 \%)$ and grants $(-0.04 \%)$ as well as the rise in the revenue expenditures $(2.1 \%)$ have increased the deficits.

In Punjab the revenue expenditures have increased $1.21 \%$ more than the RR. Although the own revenue and grants have increased by $1.9 \%$ and $0.08 \%$ respectively, the central shared taxes have declined by $-0.19 \%$ and revenue expenditures have increased by $3 \%$. Thus the RD increased by one percentage.

Among the MIGS highest RD have been observed in Kerala and West Bengal. In Kerala the deficit has increased by $1.35 \%$ due to increase in revenue expenditure $(1.2 \%)$ over the revenue receipt $(0.18 \%)$. marginal rise $(0.1 \%)$ in own revenue, declining central shared taxes $(0.24 \%)$ and grants $(0.04 \%)$ and increased revenue expenditures $(1.2 \%)$. Increased RD of $1.56 \%$ has been observed in West Bengal due to $1.53 \%$ excess increase in revenue expenditures over the RR. However, marginal rise in deficits have been found in AP and Karnataka.

When FRBMA during $12^{\text {th }}$ UFC along with the increased weightage of tax effort $(7.5 \%)$ and fiscal discipline (7.5\%) criterion in the distribution of central shared taxes more contraction in RD was seen in LIGS and HIGS and MIGH (see Appendix III). All states introduced FRBMA, but targets were not achieved by HIGS and MIGS (See Appendix III). Specifically Punjab, Kerala and West Bengal did not fulfill the targets. Although RD has reduced by $1.83 \%$ in Punjab the decline in own revenue $(-0.4 \%)$ has not enabled the state to eliminate the RD even if the central shared taxes and grants have increased by $0.45 \%$ and $0.78 \%$ respectively. In all other HIGS even if there has been marginal decline in the own revenue from $11^{\text {th }} \mathrm{FC}$ to $12^{\text {th }} \mathrm{FC}$ the significant decline in revenue expenditures has enabled them to eliminate deficit and generate revenue surpluses.

In Kerala RD has reduced by $1.92 \%$ due to rise in central shared taxes and grants by 0.24 and $0.43 \%$ respectively and fall in revenue expenditures $(1.2 \%)$. The own revenue has remained constant. If the own revenue had increased the RD could have been eliminated. Similarly in West Bengal, RD could not be removed due to its high level even if there has been marginal rise $(1.2 \%)$ in RR and decline $(0.3 \%)$ in revenue expenditures. The RR have increased due to increase in own revenue, central shared taxes and grants by $0.4 \%, 0.48 \%$ and 
$0.33 \%$ respectively. The revenue surpluses have been generated in all other MIGS due to significant rise in own revenue and fall in revenue expenditures.

In all LIGS the RR have increased over revenue expenditures due to rise in own revenue as well as central shared taxes and grants so that they have been enabled to generate revenue surpluses eliminating the revenue deficits. It has been estimated that the rise in central shared taxes and grants is greater than that of the own revenue in all states. However, Bihar, UP and Rajasthan has not been able to meet the target of FD due to excessive FD in previous FC period.

\subsection{Contradicting Methodologies and Fiscal Imbalances}

The persistence increased deficits across HIGS and MIGS over different FC periods reflects two sets of inferences. The first set of inferences derived from state finances from $7^{\text {th }}$ to $11^{\text {th }}$ FC periods includes increased revenue expenditures and grants as well as declining share of central shared taxes and own revenue. The second set of inferences derived from the state finances during $12^{\text {th }} \mathrm{FC}$ period is declining revenue expenditures, marginal rise in own revenue as well as the share of central shared taxes and grants.

From the first set of inferences it seems that states have increased (1) the gap between non plan revenue expenditure and the sum of own revenue and central share taxes to get more gap grant, (2) revenue expenditure financed through more loan to get more grant from PC, (3) the proportion of interest payment which is a components of revenue expenditure raising loan to avail more gap grants and grant from PC, and (4) the equity principle have increased the gap between non plan revenue expenditure and the sum of shared tax and own revenue of HIGS and MIGS. As a result grants to these states have increased.

Thus it is cleared that deficits are the result of complementarities of gap filling approach (GFA) and equity principle of FC and Gadgil formula of $\mathrm{PC}^{16}$ (see Table 8). According to the GFA the rise or fall in gap grants depends on expansion and contraction of the gap between non plan revenue expenditure and sum of central shared taxed and own revenue of states, which in turn depends on the tax effort of states, the weightage assigned to equity and fiscal discipline criterion, the proportion of loans as well as non- plan revenue expenditures on general, social and economic services. There is direct relationship between the gap and the second, fourth and fifth variables on the part of the HIGS and MIGS ${ }^{17}$. There is indirect

\footnotetext{
16 Initially (first three finance commission period) the gap grants were given to states on the basis of difference between the sum of central share taxes and own revenue of states as well as revenue expenditure.

17 However, the relationship between the gap and the weightage assigned to equity criterion is indirect in case of
} LIGS. 
relationship between the gap and the first and third variable on the part of the HIGS and MIGS. The GFA pursues either tax laxity ${ }^{18}$ or increasing non-plan revenue expenditures or both to all states while the EP with increasing weights reduces the share of better off states from central shared taxes which help to get more gap grants ${ }^{19}$. Elsewhere it has been mentioned that GFA encourages tax laxity and wasteful expenditures (Rao and Sen 1996, p 147: Rao and Chelliah 1996, p 25).

The GF of PC encourages borrowing of states from the centre to avail more grants because grant rooted through this formula are determined by the proportion of loan by the states $^{20}$. It supplements states to reap the implicit benefit of increased non-plan revenue expenditures as well as tax laxity through GFA. Due to less possibility of positive gap in the later formula in HIGS and MIGS and increasing weightage of equity principle in the distribution of central shared taxes (See success of states section of GFA of the Table 8), these states tried to take benefits through $\mathrm{GF}^{21}$ raising the non-plan unproductive expenditures (interest payments and pensions) increasing loans and decreasing own revenue. Thus the increasing gap under GFA complements GF to raise the proportion of loan. The increased loans being spend on the plan revenue expenditures produced no return leading to $\mathrm{RD}$ and increased FD (borrowing outstanding loans and interest payment). It has been argued that the steady financial deterioration of states is due to accumulation of state debts (Kannan et al 2004, p 480). When MTFRP was introduced along with $12.5 \%$ weightage of fiscal discipline criteria during $11^{\text {th }} \mathrm{FC}$ to restructure the state finances, deficit could not be reduced. It seems that state might have compared the benefits of these programmes with combined benefits of GFA, EP and GF since the former contradicts with the later and bypass the former due to its small size (see Table 8 column-10 row-6). Elsewhere it is argued that because the size of the cake under MTFRP is small (2\% total transfers) general category states bypass the benefits ought to be received through MTFRP (Rao 2004 p. 1823).

\footnotetext{
18 The tax laxity occurs in the form of tax exemption and absence of control on tax evasion and avoidance.

19 The weight of income distance method and inverse income method used as equity principle has increased from 25 per cent since $7^{\text {th }}$ FC period to 62.5 per cent in $11^{\text {th }} \mathrm{FC}$ and further declined to 50 per cent in $12^{\text {th }}$ FC. These methods reduce the share of HIGS and MIGS on central share taxes due to negative relationship between fiscal capacity and the share of these taxes of state.

20 Although there have been minor modifications in the GF, the basic structure remains the same.

21 With continuous increase in the share of states on central shared taxes over different UFCs and higher own revenue in the HIGS and MIGS the post devolution gap has declined.
} 
Table 8: Contradicting Formulae

\begin{tabular}{|c|c|c|c|c|c|c|c|c|c|}
\hline Formulae & Time & FC & Objective & Conditions & CoMF & CoNF & Process of Contradiction & SS & FS \\
\hline GFA & $\begin{array}{l}1952- \\
53 \text { to } \\
2014- \\
15\end{array}$ & $1 \mathrm{st}-13^{\text {th }}$ & $\begin{array}{l}\text { Maintain } \\
\text { horizontal } \\
\text { balance }\end{array}$ & $\begin{array}{l}\text { Non-Plan Tax revenue } \\
\text { account deficit }\end{array}$ & & $\begin{array}{l}\text { (1) } \\
\text { MTFRP } \\
\text { (2) } \\
\text { FRBMA } \\
\text { (3) FDC }\end{array}$ & $\begin{array}{l}\text { GFA: The objective behind GPA is to devolve as per the } \\
\text { deficiency in fiscal capacity (Non-Plan revenue account } \\
\text { gap) of states. This gap grants induces states to lax in own } \\
\text { revenue generation and increase revenue expenditure on } \\
\text { the maintenance of socio economic services and interest } \\
\text { payment. This nature of fiscal deficiency calls for rise in } \\
\text { loan which further accelerate deficits (RD and FD). On } \\
\text { the other hand the conditions of MTFRP, FRBM and FD } \\
\text { encourages to bring improvement in own revenue and } \\
\text { reduction in revenue expenditure (both plan and non-plan) } \\
\text { results in reduction in deficits. }\end{array}$ & $\begin{array}{l}\text { Odisha, WB and } \\
\text { Rajasthan ( } 7^{\text {th }} \\
\text { FC) (Rao and } \\
\text { Chelliah, 1996, p. } \\
\text { 26; Rao and Sen, } \\
\text { 1996, p. 147) }\end{array}$ & $\begin{array}{l}\text { All major states } \\
\text { except } \\
\text { Odisha, WB and } \\
\text { Rajasthan } \\
\text { ( } 7^{\text {th }} \text { FC) (Rao and } \\
\text { Chelliah, } \\
\text { 1996, p. 26; } \\
\text { Rao and Sen, } \\
\text { 1996, p. 147) }\end{array}$ \\
\hline GF & $\begin{array}{c}1969- \\
70 \text { to } \\
2014- \\
15\end{array}$ & $\begin{array}{l}5^{\text {th }}- \\
13^{\text {th }}\end{array}$ & $\begin{array}{l}\text { Maintain } \\
\text { horizontal } \\
\text { balance }\end{array}$ & $\begin{array}{l}\text { (1) } 1: 0.42 \text { loans and grants } \\
\text { ratio for } \\
\text { general category states } \\
\text { (2) } 1: 9 \text { loans and grants } \\
\text { ratio } \\
\text { for special category states }\end{array}$ & GFA & $\begin{array}{l}(1) \\
\text { MTFRP } \\
\text { (2) } \\
\text { FRBMA } \\
\text { (3) FDC }\end{array}$ & $\begin{array}{l}\text { GF: Gadgil formula is a combination of Population } \\
\text { criterion, equity principle, Fiscal discipline, and Special } \\
\text { problem. As per the norm of Gadgil formula, higher the } \\
\text { loan higher will be the loan (Rs } 0.42 \text { and Rs } 9 \text { of grants } \\
\text { for every rupees of loan to general and special categories } \\
\text { state respectively). In other words, it encourages states } \\
\text { increase in borrowing. Since borrowing is directly } \\
\text { compensated by the central government through GF, it } \\
\text { encourages states not to rethink about revenue generation } \\
\text { through increase in tax effort and expansion of tax base. } \\
\text { This fortunately complemented by the conditions of GFA. } \\
\text { On the other hand the conditions of MTFRP, FRBM and } \\
\text { FD encourages to bring improvement in own revenue and } \\
\text { reduction in revenue expenditure (both plan and non-plan) } \\
\text { results in reduction in deficits. }\end{array}$ & $\begin{array}{l}\text { HIGS (Rao and } \\
\text { Sen, 1996, p. } \\
\text { 151) }\end{array}$ & $\begin{array}{l}\text { MIGS (Rao and } \\
\text { Sen, } \\
1996, \text { p. 151) }\end{array}$ \\
\hline EP & & & $\begin{array}{l}\text { Maintain } \\
\text { horizontal } \\
\text { balance }\end{array}$ & & $\begin{array}{c}\text { GFA } \\
\text { (HIGS } \\
\& \text { MIGS) }\end{array}$ & $\begin{array}{l}\text { (1) } \\
\text { MTFRP } \\
\text { (2) } \\
\text { FRBMA } \\
\text { (3) FDC }\end{array}$ & $\begin{array}{l}\text { EP: The EP argues for progressive distribution of share } \\
\text { taxes. As a result the high income group states gets less as } \\
\text { compared to the middle and low income group state. Here } \\
\text { the High income group states in order to avail the benefits } \\
\text { of GFA, increases the gap between revenue and } \\
\text { expenditure by either (1) tax lexity, or (2) increase in non } \\
\text { plan revenue expenditure, or (3) both. This contradicts } \\
\text { with the fundamentals of MTFRP, FRBM and FD. }\end{array}$ & LIGS & MIGS and HIGS \\
\hline FDC & & & $\begin{array}{l}\text { Increase } \\
\text { efficiency } \\
\text { among states }\end{array}$ & & $\begin{array}{c}(1) \\
\text { MTFRP } \\
(2) \\
\text { FRBMA }\end{array}$ & $\begin{array}{l}\text { (1) GFA } \\
\text { (2) GF } \\
\text { (3) EP }\end{array}$ & $\begin{array}{l}\text { FDC tries to reduce deficits but GFA, GF and EP } \\
\text { encourage deficits }\end{array}$ & & \\
\hline MTFRP & $\begin{array}{l}2000- \\
01 \text { to } \\
2004-\end{array}$ & $11^{\text {th }}$ & $\begin{array}{l}\text { To increase } \\
\text { efficiency } \\
\text { among states }\end{array}$ & $\begin{array}{l}\text { (1) Zero RD } \\
\text { (2) GFD to } 2.5 \% \text { of GSDP } \\
\text { (3) IP to be less than } 18-\end{array}$ & FDC & $\begin{array}{l}\text { (1) GFA } \\
\text { (2) GF } \\
\text { (3) } \mathrm{EP}\end{array}$ & $\begin{array}{l}\text { MTFRP tries to reduce deficits but GFA, GF and EP } \\
\text { encourage deficits thereby inefficiency. }\end{array}$ & $\begin{array}{l}\text { Special Category } \\
\text { States (Rao, } \\
\text { 2004, p. 1823) }\end{array}$ & $\begin{array}{l}\text { General Category } \\
\text { States } \\
\text { (Rao, 2004, p. }\end{array}$ \\
\hline
\end{tabular}

Page $\mathbf{2 0}$ of $\mathbf{2 7}$ 


\begin{tabular}{|c|c|c|c|c|c|c|c|c|c|}
\hline & 05 & & & $\begin{array}{l}20 \% \text { of RR } \\
\text { (4) Wages and Salaries less } \\
\text { than } 5 \% \text { of the } \\
\text { increase in CPI } \\
\text { (5) increase in IP not be } \\
\text { more than } 10 \% \text { per year } \\
\text { (6) Explicit subsidies to be } \\
50 \% \text { over five year period }\end{array}$ & & & & & 1823) \\
\hline FRBMA & $\begin{array}{c}2005- \\
06 \text { to } \\
2009- \\
10\end{array}$ & $12^{\text {th }}$ & $\begin{array}{l}\text { To bring fiscal } \\
\text { discipline } \\
\text { among states }\end{array}$ & $\begin{array}{l}\text { (1) Zero RD by 2008-09 } \\
\text { (2) FD to } 3 \% \text { of GSDP/ } \\
\text { ratio of IP to RR } \\
\text { (3) Annual targets for RD } \\
\text { and FD } \\
\text { (4) Annual statements on } \\
\text { prospects for the state } \\
\text { economy and related fiscal } \\
\text { strategy } \\
\text { (5) special statements of } \\
\text { budget giving in detail the } \\
\text { number of employees in } \\
\text { government, public sector, } \\
\text { aided institutions and } \\
\text { related salaries }\end{array}$ & FDC & $\begin{array}{l}\text { (1) GFA } \\
\text { (2) GF } \\
\text { (3) EP }\end{array}$ & $\begin{array}{l}\text { FRBMA tries to reduce deficits but GFA, GF and EP } \\
\text { encourage deficits thereby inefficiency. }\end{array}$ & $\begin{array}{l}\text { Goa, Punjab, } \\
\text { Haryana, } \\
\text { Maharastra, } \\
\text { Kerala, Gujarat, } \\
\text { Tamilnadu, } \\
\text { Karnataka, AP } \\
\text { and WB (Rao and } \\
\text { Jena, 2005, p. } \\
\text { 3409) }\end{array}$ & $\begin{array}{l}\text { Rajasthan, } \\
\text { Chhatisgarh, } \\
\text { MP, Jharkhand, } \\
\text { Odisha,UP and } \\
\text { Bihar } \\
\text { (Rao and Jena, } \\
\text { 2005, p.3409) }\end{array}$ \\
\hline
\end{tabular}

GFA = Gap Filling Approach, GF = Gadgil Formula, EP = Equity Principle, FDC = Fiscal Discipline Criterion, MTMRP = Medium Term Fiscal Restructuring Programme, FRBMA = Fiscal Responsibility and Budget Management Act, FC = Finance Commission, CoMF = Complementary Formulae, CoNF = Contradicting Formulae, RR $=$ Revenue Receipt, IP = Interest Payment and NPRE = Non Plan

Source: $\quad$ Revenue Expenditures, SS = Success States, FS = Failure States. 
From the second set of inferences it may be inferred that when FRBMA was introduced during $12^{\text {th }} \mathrm{FC}$ states compared the benefits of the traditional methods (GFA, $\mathrm{EP}$ and GF) with that of new programmes and the weightage of fiscal discipline criterion and accepted / rejected the former depending on its size of the benefits relative to the later (see Table 8- column 9 \& 10 Row-7).

Thus depending on the relative benefits of the traditional methods and the new programmes, states started increasing or decreasing deficits (see appendix IV \& V). However, the better off states could play the game more tactfully than the poorer states due to their large budget size. They are Gujarat, Maharastra and Punjab among the HIGS and Kerala and West Bengal among the MIGS. Elsewhere it has been stated that Maharastra, Punjab, Kerala and West Bengal have been failed to achieve the targets of FRBMA (Ravishankar, Zahir and Kaul 2008, p 60). While Gujarat and West Bengal have declined their own revenue effort and thereby reducing the amount of own revenue the other three have increased the revenue expenditures.

\section{Part V}

\section{Conclusion}

With diverse socio-economic characteristics of the country, federal structure of government has been adopted to provide all nationals common minimum level of basic public goods per unit of tax price. Even if the design of the structure is in line with the economic principle of fiscal federalism, fiscal imbalances are found to be increasing overtime. The complementarities of methods having same objectives and contradicting methods with different objectives of UFC and PC create a paradox in the process of central devolution which accentuated fiscal imbalances. Rich states have been discouraged to improve their revenue capacity imposing revenue burden on people when equity objective is given more emphasis. In the same line poor states suffer when higher weightage is assigned to efficiency criterion. With this conflicting situation reforms in the transfer system are of crucial importance which should be considered by the $14^{\text {th }} \mathrm{FC}$. 


\section{Appendices}

\section{Appendix I: Deficits of Centre, States}

\begin{tabular}{ccccccccc}
\hline \multicolumn{7}{c}{ Deficits of Centre } & & \multicolumn{3}{c}{ Deficits of State } \\
\hline & RD\%GDP & RD\%FD & FD\%GDP & PD\%GDP & RD\%GDP & RD\%FD & FD\%GDP & $\begin{array}{c}\text { PD\% } \\
\text { GDP }\end{array}$ \\
\hline $1980-81$ & 1.5 & 24.5 & 6.1 & 4.2 & -1.1 & -40.0 & 2.7 & 1.8 \\
\hline $1981-82$ & 0.2 & 4.5 & 5.4 & 3.4 & -0.9 & -33.9 & 2.5 & 1.6 \\
\hline $1982-83$ & 0.7 & 12.3 & 5.9 & 4.9 & -0.5 & -17.8 & 2.8 & 1.8 \\
\hline $1983-84$ & 1.2 & 19.5 & 6.2 & 3.9 & -0.1 & -3.3 & 3.0 & 2.1 \\
\hline $1984-85$ & 1.8 & 24.3 & 7.4 & 4.9 & 0.4 & 11.3 & 3.5 & 2.4 \\
\hline $1985-86$ & 2.2 & 26.9 & 8.3 & 5.5 & -0.2 & -8.7 & 2.9 & 1.7 \\
\hline $1986-87$ & 2.7 & 29.5 & 9.0 & 5.8 & -0.1 & -1.8 & 3.2 & 1.8 \\
\hline $1987-88$ & 2.8 & 33.8 & 8.1 & 4.8 & 0.3 & 9.7 & 3.4 & 1.9 \\
\hline $1988-89$ & 2.7 & 34.0 & 7.8 & 4.2 & 0.5 & 15.5 & 2.9 & 1.4 \\
\hline $1989-90$ & 2.6 & 33.4 & 7.8 & 3.9 & 0.8 & 23.9 & 3.4 & 1.8 \\
\hline $1990-91$ & 3.5 & 41.6 & 8.4 & 4.4 & 1.0 & 28.3 & 3.5 & 1.9 \\
\hline $1991-92$ & 2.7 & 44.8 & 5.9 & 1.6 & 0.9 & 29.9 & 3.1 & 1.3 \\
\hline $1992-93$ & 2.6 & 46.3 & 5.7 & 1.3 & 0.7 & 24.5 & 3.0 & 1.1 \\
\hline $1993-94$ & 4.0 & 54.3 & 7.4 & 2.9 & 0.5 & 19.0 & 2.5 & 0.6 \\
\hline $1994-95$ & 3.2 & 53.8 & 6.0 & 1.4 & 0.7 & 24.6 & 2.9 & 0.8 \\
\hline $1995-96$ & 2.7 & 49.4 & 5.4 & 0.9 & 0.8 & 27.9 & 2.8 & 0.8 \\
\hline $1996-97$ & 2.5 & 48.9 & 5.1 & 0.6 & 1.3 & 46.2 & 2.8 & 0.9 \\
\hline $1997-98$ & 3.2 & 52.2 & 6.1 & 1.6 & 1.2 & 40.2 & 3.0 & 0.9 \\
\hline $1998-99$ & 4.0 & 59.1 & 6.8 & 2.1 & 2.7 & 60.7 & 4.4 & 2.3 \\
\hline $1999-2000$ & 3.6 & 64.6 & 5.6 & 0.8 & 2.9 & 60.5 & 4.8 & 2.4 \\
\hline $2000-01$ & 4.3 & 71.7 & 5.9 & 1.0 & 2.8 & 62.9 & 4.4 & 1.8 \\
\hline $2001-02$ & 4.6 & 71.1 & 6.5 & 1.5 & 2.8 & 64.1 & 4.3 & 1.5 \\
\hline $2002-03$ & 4.6 & 74.4 & 6.2 & 1.2 & 2.4 & 57.3 & 4.3 & 1.3 \\
\hline $2003-04$ & 3.7 & 79.7 & 4.7 & 0.0 & 2.4 & 52.6 & 4.6 & 1.5 \\
\hline $2004-05$ & 2.6 & 62.3 & 4.2 & 0.0 & 1.3 & 36.3 & 3.6 & 0.7 \\
\hline $2005-06$ & 2.7 & 63.0 & 4.3 & 0.4 & 0.2 & 7.8 & 2.7 & 0.2 \\
\hline $2006-07$ & 2.0 & 56.3 & 3.6 & -0.2 & -0.6 & -32.1 & 2.0 & -0.4 \\
\hline $2007-08$ & 1.1 & 41.4 & 2.8 & -1.0 & -0.9 & -56.9 & 1.6 & -0.5 \\
\hline $2008-09$ & 4.8 & 75.2 & 6.4 & 2.7 & -0.2 & -9.4 & 2.5 & 0.6 \\
\hline $2009-10$ & 5.5 & 81.0 & 6.8 & 3.3 & 0.5 & 16.4 & 3.1 & 1.2 \\
\hline Sources: For GDP at Current & Prices, CSO & webite, http://mospi.nic.in/Mospi-New/site/home.aspx and for & \\
\hline
\end{tabular}

Deficits the same source as Table 1. 


\begin{tabular}{|c|c|c|c|c|c|c|}
\hline \multicolumn{7}{|l|}{$\begin{array}{l}\text { Appendix } \\
\text { GSDP) }\end{array}$} \\
\hline States & OR & CST & GR & $\mathrm{RR}$ & $\mathrm{RE}$ & $\mathrm{RD}$ \\
\hline \multicolumn{7}{|l|}{ HIG } \\
\hline Gujarat & 0.10 & -0.35 & 0.58 & 0.32 & 2.30 & 1.98 \\
\hline Haryana & -1.70 & -0.40 & -0.14 & -2.24 & -3.50 & -1.25 \\
\hline Maharastra & 0.70 & -0.18 & -0.04 & 0.49 & 2.10 & 1.63 \\
\hline Punjab & 1.90 & -0.19 & 0.08 & 1.79 & 3.00 & 0.99 \\
\hline \multicolumn{7}{|l|}{ MIG } \\
\hline Andhra Pradesh & 1.50 & -0.63 & 0.12 & 0.99 & 1.30 & 0.12 \\
\hline Karnataka & 2.10 & 0.02 & 0.36 & 2.48 & 1.70 & 0.30 \\
\hline Kerala & 0.10 & -0.24 & -0.04 & -0.18 & 1.20 & 1.35 \\
\hline Tamilnadu & 1.00 & -0.20 & 0.15 & 0.95 & 0.90 & -0.06 \\
\hline West Bengal & 0.10 & 0.33 & 0.34 & 0.77 & 2.30 & 1.56 \\
\hline \multicolumn{7}{|l|}{ LIG } \\
\hline Bihar & 0.60 & 2.93 & 0.93 & 4.47 & 4.30 & 0.13 \\
\hline Madhya Pradesh & 1.30 & 1.07 & 0.30 & 2.67 & 2.40 & -0.24 \\
\hline Orissa & 1.50 & 1.20 & 0.13 & 2.83 & 0.40 & -0.61 \\
\hline Rajasthan & 0.70 & 0.64 & 0.44 & 1.77 & 2.70 & 0.94 \\
\hline Uttar Pradesh & 1.40 & 1.25 & 0.38 & 3.03 & 3.80 & 0.77 \\
\hline
\end{tabular}

Note: $\quad$ Same as Table 5.

Source: Same as Table 1.

\begin{tabular}{|c|c|c|c|c|c|c|}
\hline \multicolumn{7}{|c|}{$\begin{array}{l}\text { Appendix III: Change of indicators of State Finances from } 11^{\text {th }} \text { to } 12^{\text {th }} \text { FC (\%o } \\
\text { GSDP) }\end{array}$} \\
\hline States & OR & ST & GR & $\mathrm{RR}$ & $\mathrm{RE}$ & $\mathrm{RD}$ \\
\hline \multicolumn{7}{|l|}{ HIG } \\
\hline Gujarat & -1.17 & 0.51 & -0.13 & -0.79 & -4.43 & -3.65 \\
\hline Haryana & 0.21 & 0.29 & 0.22 & 0.72 & -0.56 & -1.29 \\
\hline Maharastra & -0.32 & 0.19 & 0.89 & 0.76 & -2.41 & -3.17 \\
\hline Punjab & -0.40 & 0.45 & 0.78 & 0.83 & -1.00 & -1.83 \\
\hline \multicolumn{7}{|l|}{ MIG } \\
\hline Andhra Pradesh & 1.86 & 0.84 & 0.68 & 3.39 & 0.96 & -2.22 \\
\hline Karnataka & 1.30 & 0.19 & 0.60 & 2.09 & -0.24 & -2.34 \\
\hline Kerala & 0.04 & 0.24 & 0.43 & 0.71 & -1.20 & -1.92 \\
\hline Tamilnadu & 1.10 & 0.43 & 0.60 & 2.13 & -0.17 & -2.30 \\
\hline West Bengal & 0.37 & 0.48 & 0.33 & 1.18 & -0.35 & -1.53 \\
\hline \multicolumn{7}{|l|}{ LIG } \\
\hline Bihar & 0.41 & 2.83 & 1.91 & 5.15 & 1.79 & -3.03 \\
\hline Madhya Pradesh & 0.87 & 1.30 & 1.50 & 3.67 & 0.18 & -3.49 \\
\hline Orissa & 0.81 & 0.76 & 1.04 & 2.61 & -1.85 & -4.46 \\
\hline Rajasthan & 1.28 & 1.05 & 0.23 & 2.55 & -0.79 & -3.33 \\
\hline Uttar Pradesh & 1.94 & 2.36 & 1.44 & 5.74 & 1.07 & -4.66 \\
\hline
\end{tabular}

Note: $\quad$ Same as Table 5.

Source: Same as Table 1. 


\section{Appendix IV: Commission wise Revenue Deficits (\% of GSDP)}

\begin{tabular}{lccccccc}
\hline State & $7^{\text {th }}$ & $8^{\text {th }}$ & $9^{\text {th }}-1$ & $9^{\text {th }}-2$ & $10^{\text {th }}$ & $11^{\text {th }}$ & $12^{\text {th }}$ \\
\hline HIGS & & & & & & & FC \\
\hline Gujarat & -1.07 & 0.77 & 0.46 & 0.81 & 1.62 & 3.60 & -0.05 \\
\hline Haryana & -1.24 & -0.84 & 0.75 & 0.28 & 2.09 & 0.84 & -0.44 \\
\hline Maharastra & -0.68 & 0.43 & 0.64 & 0.22 & 1.22 & 2.85 & -0.31 \\
\hline Punjab & -0.88 & 0.52 & 1.21 & 2.24 & 2.99 & 3.98 & 2.16 \\
\hline Average & $\mathbf{- 1 . 0}$ & $\mathbf{0 . 2}$ & $\mathbf{0 . 8}$ & $\mathbf{0 . 9}$ & $\mathbf{2 . 0}$ & $\mathbf{2 . 8}$ & $\mathbf{0 . 3}$ \\
\hline MIGS & & & & & & & \\
\hline Andhra Pradesh & -0.59 & 0.39 & 0.77 & 0.34 & 1.66 & 1.78 & -0.43 \\
\hline Karnataka & -0.99 & 0.42 & 0.64 & 0.32 & 0.94 & 1.23 & -1.10 \\
\hline Kerala & -0.19 & 1.01 & 1.58 & 1.53 & 2.56 & 3.91 & 1.99 \\
\hline Tamilnadu & -0.83 & 0.11 & 1.50 & 2.12 & 1.76 & 1.70 & -0.60 \\
\hline West Bengal & 0.91 & 0.61 & 1.35 & 1.54 & 3.40 & 4.96 & 3.43 \\
\hline Average & $-\mathbf{0 . 3}$ & $\mathbf{0 . 5}$ & $\mathbf{1 . 2}$ & $\mathbf{1 . 2}$ & $\mathbf{2 . 1}$ & $\mathbf{2 . 7}$ & $\mathbf{0 . 7}$ \\
\hline LIGS & & & & & & & \\
\hline Bihar & -0.20 & -1.21 & 0.12 & 1.82 & 1.74 & 1.87 & -1.16 \\
\hline Madhya Pradesh & -1.57 & -0.07 & -0.33 & 0.23 & 1.76 & 1.53 & -1.96 \\
\hline Orissa & -0.50 & 0.77 & 0.81 & 1.05 & 3.95 & 3.35 & -1.11 \\
\hline Rajasthan & -0.80 & 1.04 & 0.16 & 0.27 & 2.40 & 3.33 & 0.0 \\
\hline Uttar Pradesh & -0.79 & 0.22 & 1.85 & 1.41 & 3.15 & 3.92 & -0.74 \\
\hline Average & $-\mathbf{0 . 8}$ & $\mathbf{0 . 2}$ & $\mathbf{0 . 5}$ & $\mathbf{1 . 0}$ & $\mathbf{2 . 6}$ & $\mathbf{2 . 8}$ & $\mathbf{- 1 . 0}$ \\
\hline Sorat Sa & & & & & & &
\end{tabular}

Source: Same as Table 4.

\section{Appendix V: Commission wise Fiscal Deficits (\% of GSDP)}

\begin{tabular}{lccccccc}
\hline & $7^{\text {th }} \mathrm{FC}$ & $8^{\text {th }} \mathrm{FC}$ & $\begin{array}{c}9^{\text {th }}-1 \\
\mathrm{FC}\end{array}$ & $\begin{array}{c}9^{\text {th }}-2 \\
\mathrm{FC}\end{array}$ & $\begin{array}{c}10^{\text {th }} \\
\mathrm{FC}\end{array}$ & $\begin{array}{c}11^{\text {th }} \\
\text { HIGS }\end{array}$ & $\begin{array}{c}12^{\text {th }} \\
\text { HCC }\end{array}$ \\
\hline Gujarat & & & & & & & \\
\hline Haryana & 3.0 & 4.1 & 3.5 & 3.4 & 4.0 & 5.4 & 2.6 \\
\hline Maharastra & 2.8 & 2.8 & 3.1 & 2.2 & 3.6 & 3.0 & 1.3 \\
\hline Punjab & 2.7 & 3.3 & 3.2 & 2.3 & 3.3 & 4.5 & 2.2 \\
\hline Average & 2.9 & 5.4 & 5.0 & 4.9 & 4.4 & 5.3 & 3.7 \\
\hline MIGS & $\mathbf{2 . 9}$ & $\mathbf{3 . 9}$ & $\mathbf{3 . 7}$ & $\mathbf{3 . 2}$ & $\mathbf{3 . 8}$ & $\mathbf{4 . 5}$ & $\mathbf{2 . 4}$ \\
\hline Andhra Pradesh & & & & & & & \\
\hline Karnataka & 2.4 & 3.2 & 3.1 & 3.0 & 3.4 & 4.3 & 3.0 \\
\hline Kerala & 2.6 & 3.5 & 2.7 & 2.8 & 3.0 & 3.8 & 2.6 \\
\hline Tamilnadu & 2.4 & 3.3 & 3.8 & 3.4 & 4.4 & 5.0 & 3.1 \\
\hline West Bengal & 2.4 & 2.3 & 2.9 & 2.8 & 2.8 & 3.4 & 1.9 \\
\hline Average & 2.7 & 1.8 & 3.0 & 2.9 & 5.1 & 6.7 & 4.3 \\
\hline LIGS & $\mathbf{2 . 5}$ & $\mathbf{2 . 8}$ & $\mathbf{3 . 1}$ & $\mathbf{3 . 0}$ & $\mathbf{3 . 7}$ & $\mathbf{4 . 6}$ & $\mathbf{3 . 0}$ \\
\hline Bihar & & & & & & & \\
\hline Madhya Pradesh & 3.4 & 2.5 & 3.6 & 3.7 & 3.2 & 5.5 & 4.9 \\
\hline Orissa & 2.7 & 3.2 & 2.4 & 2.3 & 3.0 & 4.5 & 2.3 \\
\hline Rajasthan & 3.2 & 4.7 & 4.4 & 4.7 & 6.2 & 5.9 & 0.9 \\
\hline Uttar Pradesh & 4.3 & 4.4 & 3.0 & 3.4 & 5.3 & 6.0 & 3.1 \\
\hline Average & 3.0 & 3.7 & 4.5 & 4.1 & 5.0 & 5.6 & 4.2 \\
\hline Source: Same as Table 4 & $\mathbf{3 . 3}$ & $\mathbf{3 . 7}$ & $\mathbf{3 . 6}$ & $\mathbf{3 . 6}$ & $\mathbf{4 . 5}$ & $\mathbf{5 . 5}$ & $\mathbf{3 . 1}$ \\
\hline
\end{tabular}




\section{References}

Ahluwalia, Montek (2000): "Economic Performance of States in Post Reform Period", Economic and Political Weekly, Vol. XXXV, No. 19, May 6, pp 1637-48.

Bagchi, Amaresh and Pinaki Chakraborty (2004): "Towards a Rational System of Centre- State Revenue Transfers", Economic and Political Weekly, Vol. XXXIX, No.26, June 26-July 2, pp 2737-2747.

Chakraborty, P (1998): “Growing Imbalances in Federal Fiscal Relationship", Economic and Political Weekly, Vol. XXXIII, No.7, February 14-20, pp 350-354.

Chakraborty, P (2010): "Deficit Fundamentalism vs Fiscal Federalism: Implications of $13^{\text {th }}$ Finance Commission's Recommendations", Economic and Political Weekly, Vol. XLV, No.48, November 27-Decembe 3, pp 65-63.

Chelliah, R J (2005): "Malady of Continuing Fiscal Imbalance", Economic and Political Weekly, Vol. XL, No.31, July 30-August 5, pp 3399-3404.

Chelliah, Raja J, M G Rao and T K Sen (1992): “Issues before Tenth Finance Commission”, Economic and Political Weekly, Vol. XXVII, No.47. , November 21-27, pp 2539-2550.

Ghosh, Jayati (2005): "Twelfth Finance Commission and Restructuring of State Government Debt: A Note.” Economic and Political Weekly, Vol. XL, No.31 July 30 - August 5, pp 3435-3439.

Kannan, R; S N Pillai; R Kausaliya and Jai Chander (2004): "Finance Commission Awards and Fiscal Stability in States", Economic and Political Weekly, Vol. XXXIX. No.5, January 31- August 5, pp 3399-3404.

Kurian, N J (2005): "Debt Relief for States" Economic and Political Weekly, Vol. XL, No.31, July 30 - August 5, pp 3429-34, .

Lalvani, Mala (2009): "Persistence of Fiscal Irresponsibility: Looking Deeper into Provisions of FRBM Act”, Economic and Political Weekly, Vol. XLIV, No. 37, September 12, pp 5763.

Mukhopadhyay, Hiranya and Kuntal Kumar Das (2003): "Horizontal Imbalances in India: Issues and Determinants", Economic and Political Weekly, Vol. XXXVIII. , No.14, April 5-11, pp 1416-1420

Mukhopadyay, Debes (2003): “Centre State Financial Relations in India”, in P K Chaubey, (eds.), Fiscal Federalism in India, Deep and Deep Publications PVT. LTD., New Delhi.

Raju, Swati (2012): "Growth across States in 2000: Evidence of Convergence", Economic and Political Weekly, Vol. XLVII, No 23, June 9, pp 76-79. 
Rakshit, M (2005): "Some Analytics and Empirics of Fiscal Restructuring in India", Economic and Political Weekly, Vol. XL, No 31, July 30 - Aug 5, pp 3440-3449.

Rangarajan, C (2005): “Approach and Recommendations”, Economic and Political Weekly, Vol. XL, No 31, July 30 to August 5, pp 3396-3398.

Rangarajan, C and D K Srivastava, (2005): "Fiscal Deficit and Government Debt: Implications for Growth and Stabilization", Economic and Political Weekly, Vol. XL, No. 27 July 2, pp .2919-2934.

Rao, M G and P R Jena (2005): "Balancing Stability, Equity and Efficiency”, Economic and Political Weekly, Vol. XL, No.31, July 30-August 5, pp 3405 -12.

Rao, M G (2000): “Linking Central Grants to Revenue Deficit Reduction by States", Economic and Political Weekly, Vol. XXXV, No 23, June 3-9, pp 1883-84.

Rao, M G (2002): "State Finances in India: Issues and Challenges", Economic and Political Weekly, Vol. XXXVII, No 31, August 3-9, pp 3261-3271.

Rao, M G (2003): "Incentivizing Fiscal Transfers in the Indian Federation”, The Journal of Federalism, Vol. XXXIII, No .4.

Rao, M G (2004): "Linking Central Transfers to Fiscal Performance of States", Economic and Political Weekly, Vol. XXXIX, No.18, May 1-6, pp 1820-1825.

Rao, M G \& Nirvikar Singh (2005): “Asymmetric Federalism in India.” in Richard Bird and Robert Ebel, Fiscal Fragmentation in Decentralized Countries: Subsidiary, Solidarity and Asymmetry.

Rao, M G and T K Sen (1996): Fiscal Federalism in Theory and Practice, New Delhi, Indian Council of Social Science Research.

Spant, Ronald (2003): "Why Net Domestic Product Should Replace Gross Domestic Product as a Measure of Economic Growth” International Productivity Monitor, No.7, pp 39-43

Varghese, Santhosh (2006): “Fiscal Responsibility or Fisc's Liability? Some Quick Comments on the Impact of Fiscal Targets in FRBM Acts of Sub-national States", Paper Submitted as Part of Refresher Course in Public Economics, 28 May-22 June, 2006. 


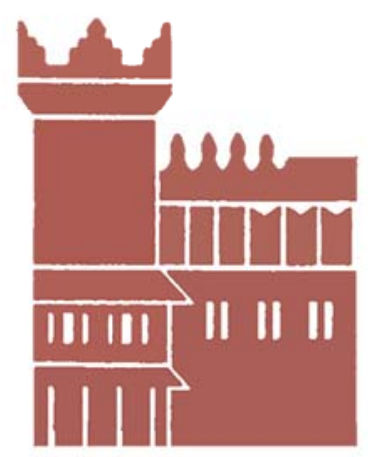

Alma Mater Studiorum - Università di Bologna DEPARTMENT OF ECONOMICS

Strada Maggiore 45

40125 Bologna - Italy

Tel. +39051 2092604

Fax +390512092664

http://www.dse.unibo.it 